\title{
Nursing teachers in clinical training areas: a phenomenological focus
}

\author{
Lorena Bettancourt ${ }^{1}$ \\ Luz Angelica Muñoz ${ }^{2}$ \\ Miriam Aparecida Barbosa Merighi ${ }^{3}$ \\ Marcia Fernandes dos Santos ${ }^{4}$
}

During theoretical and practical activities in clinical training areas, nursing teachers provide the bases needed for the development of future professionals. The goal is to understand the experience of nursing teachers with nursing students in clinical training areas. Therefore, a phenomenological qualitative method was chosen, and Martin Heidegger's philosophical framework was used to support data analysis. Five faculty from a Chilean university participated in the study. The analysis permitted discovering the following themes: being a faculty at the hospital, contact with nurse practitioners and being a faculty in care teaching. The study demonstrated that teaching/care integration is a constructive element that facilitates the teaching and learning process, aiming to prepare nursing professionals who incorporate the bases of authentic care into their activities.

Descriptors: Nursing; Education, Nursing; Qualitative Research.

\footnotetext{
${ }_{1}^{1}$ Nurse-Midwife, M.Sc. in Nursing, Assistant Professor, Universidad de Valparaíso, Chile. E-mail: lorena.bettancourt@uv.cl.

${ }^{2}$ RN, Ph.D. in Nursing, Full Professor, Facultad de Enfermería, Universidad Andres Bello, Santiago de Chile, Chile. E-mail: Imunoz@unab.cl.

${ }^{3}$ RN, Ph.D. in Nursing, Full Professor, Escola de Enfermagem, Universidade de São Paulo, SP, Brazil. E-mail: merighi@usp.br.

${ }^{4}$ RN, M.Sc. in Nursing, Assistant Professor, Universidad Andres Bello, Santiago de Chile, Chile. E-mail: marcia_fsantos@yahoo.com.br.
}

Corresponding Author:

Lorena Bettancourt

Universidad de Valparaíso

Blas Cuevas, 1028

Valparaíso, Chile

E-mail: Iorena.bettancourt@uv.cl 


\section{O docente de enfermagem nos campos de prática clínica: um enfoque fenomenológico}

No desenvolvimento das atividades teórico-práticas nos campos de prática clínica, o docente de enfermagem proporciona as bases necessárias para o desenvolvimento do futuro profissional. $\mathrm{O}$ objetivo proposto foi compreender a vivência dos docentes de enfermagem, junto aos estudantes de enfermagem, nos campos de prática clínica. Para isso, optou-se por metodologia qualitativa fenomenológica e, para fundamentar a análise dos dados, foi adotado o referencial filosófico de Martin Heidegger. Cinco docentes de uma universidade do Chile participaram do estudo. A análise possibilitou descobrir os seguintes temas: ser docente no hospital, a convivência com enfermeiras clínicas e ser docente no ensino do cuidado. O estudo demonstrou que a integração docente/ assistencial é elemento construtivo e facilitador do processo ensino/aprendizagem, buscando a formação de profissionais da enfermagem que incorporem, na sua atuação, as bases de cuidado autêntico.

Descritores: Enfermagem; Educação em Enfermagem; Pesquisa Qualitativa.

\section{El docente de enfermería en los campos de práctica clínica: un enfoque fenomenológico}

El docente de enfermería en el desarrollo de las actividades teórico-prácticas en los campos de práctica clínica proporciona las bases necesarias para el desarrollo del futuro profesional. El objetivo propuesto es comprender la vivencia de los docentes de enfermería junto a los estudiantes de enfermería, en los campos de práctica clínica. Para ello se optó por una metodología cualitativa fenomenológica, y para fundamentar el análisis de los datos, se utilizó el marco filosófico de Martín Heidegger. Cinco docentes de una universidad de Chile participaron del estudio. El análisis posibilitó descubrir los siguientes temas: ser docente en el hospital, la convivencia con enfermeras clínicas y ser docente en la enseñanza del cuidado. El estudio demostró que la integración docente/asistencial es un elemento constructivo y facilitador del proceso de enseñanza y aprendizaje, que busca la formación de profesionales de enfermería que incorporen en su actuación las bases de un cuidado auténtico.

Descriptores: Enfermería; Educación en Enfermería; Investigación Cualitativa.

\section{Introduction}

The teaching and learning process in nursing has some special characteristics, due to the fact that it is largely based on theory and practice. Also, it takes place at health service institutions that serve as clinical training areas $^{(1)}$. Although real, students' cognition does not have a palpable core. Instead, it is characteristic to each student and, therefore, inaccessible to teachers. It is known that students translate theoretical and practical knowledge, showing that these are not separate experiences $^{(2)}$.

Learning to take care necessarily happens in the relation between students and the persons receiving care, in which the former apply and transform the theoretical knowledge learned in the classroom, through practical care actions, with teachers' support. Teachers' activities in this context turn into an important element of the process as, by getting integrated into clinical units together with the students, through their personal and up-to-date knowledge, teachers provide the bases and support needed for the development of future nursing professionals $^{(3-4)}$. It is in this clinical care environment, however, where the teacher/care integration itself occurs, that nursing teachers and nurse practitioners play a fundamental role in students' education ${ }^{(5)}$. 
Teachers not only instruct, but also stimulate students to make decisions, observe, perceive relations and work with inquiries. Thus, teachers enhance students' development of skills and attitudes that lead to the acquisition of technical as well as political power, so as to be able to act to the benefit of society ${ }^{(6)}$.

The authors' experience as nurse practitioners and nursing teachers made them investigate in further depth what is currently happening in nursing teaching in clinical practice areas. One of the author's work as a teacher in an undergraduate nursing program at the University of Valparaíso, Chile, revealed the environment faculty members at that school face, sometimes warm and facilitating, other times hostile and threatening, in which they felt the tension that hampered students' learning.

It should be highlighted that students at that School of Nursing start their clinical experiences in the second year of their undergraduate program. In that and the third year, faculty members accompany them full-time. In the fourth and fifth year, supervision is partial.

In this context, teachers are responsible for: selecting patients according to the program goals, deliver care together with the students (enhancing reflections on the experience), distribute tasks, supervise and act as facilitators in the learning process. A maximum of seven students per teacher should guarantee the quality of teaching and stimulate students to start developing and integrating the knowledge they received in the theoretical blocks, besides starting to gradually integrate themselves into a professional environment and, therefore, have their first contact with nurse practitioners at the different levels of their experience.

Another element observed during performance in clinical areas refers to the anxiety some faculty reveal because they are not able to comply with course requirements, in addition to the little acknowledgement of their work by users, nurses themselves and health staff.

In this context, concerns arise about nursing faculty members' activities in clinical training areas. A systematic search of the bibliography revealed that literature emphasized more curricular aspects, which did not answer the questions that emerged though: What is it like to be with students at the hospital? How do clinical nursing teachers relate with nurse practitioners? and How do clinical nursing teachers see their role in nursing students' learning at the hospital?

These concerns needed a response, entailing the need to attempt to unveil the phenomenon: being a nursing teacher in clinical training areas.
This study is justified to the extent that it seeks the experience through the people who go through it. The meaning of this experience constitutes knowledge that can contribute to reflection and re-elaboration on nursing teachers' actions, in view of the activities they perform in clinical training areas. Hence, this research can propose bases that contribute to improve the quality of learning, care and knowledge production in nursing.

Thus, this research aims to understand the experience of nursing teachers with undergraduate students in clinical training areas.

\section{Method}

To achieve a more global understanding of the experience teachers go through based on their own perspective, a qualitative study was considered the most coherent route towards the research goals.

Qualitative research is an open process, submitted to countless and unforeseeable developments, whose organization centers around a model the researcher develops, in relation to which different empirical information gains meaning(7). In this case, the phenomenon under analysis is inserted in the context of nursing teachers' individual experiences, who perform practical teaching in the undergraduate nursing program.

In the attempt to understand the phenomenon nursing teachers go through in clinical areas, Martin Heidegger's phenomenology seems pertinent, as it seeks, without prejudices or theories, to investigate, understand and interpret the teacher being, as a concrete experience and a conscious subject. Thus, meaning is attributed, according to their own view of the world-life, according to their customs, knowledge and values, intersubjectively experienced with the others. Heidegger, in his study on existentialism, does not distinguish between reason and emotion, and questions how existence is, elucidating that this being covers the whole, whose being can be apprehended based on mundaneness, that is, an essential way of being, based on different foundations ${ }^{(8)}$

To conduct this study, the researchers looked for nursing teachers who had contact with students in practical fields and who accepted to participate in the study. Hence, the ontological region where the phenomenon was analyzed was the School of Nursing at the University of Valparaíso, Chile.

The number of subjects who participated in the study was defined after the interviews. Eight faculty 
were interviewed and the researchers worked with five of them, which were considered the richest in meanings and, moreover, were sufficient to answer the research questions.

Thus, a group of five nurses were the study participants. The interviews were held at the School of Nursing or wherever the participants found it convenient. At the time of the interview, they received general explanations about what the study involved; interviews were held between July and August 2006.

In compliance with ethical principles regarding the researcher's duty to protect interaction with the subjects, all data were collected with the participants' previous authorization and an informed consent term was signed, guaranteeing anonymity. The research protocol received approval from the University's Institutional Review Board.

Interviews took place at a previously selected place and a time previously agreed upon. Statements were recorded and the nurses were asked to freely express their experiences on the research theme, based on the following guiding question: What is the experience like for you to be with nursing students when they perform their clinical experience at the hospital?

Interviews happened on one single occasion, so that the subjects expressed their viewpoint of the moment, which spontaneously emerged from the discourse. Statements were numbered from 1 (one) to 5 (five), preceded by the letter I (interview) I1, I2, and so forth.

To analyze the interviews, the procedures phenomenology experts defined were used ${ }^{(9)}$; initially, the statements were numbered and read fully and attentively, in order to understand the global meaning, but without interpreting or identifying the attributes they contained. Next, in each statement's descriptions, the researchers looked for the evident presence of the essentialities that mark the phenomenon nursing teacher in clinical areas. Thus, the units of meaning (interview fragments) that made sense to the researchers and answered the guiding question were identified, highlighted and numbered. After obtaining the units of meaning, the researchers aimed to identify and group the units in each discourse that presented a common theme. Three themes emerged from the interviews: Being a teacher at the hospital, Having contact with nurse practitioners and Being a teacher in care education.

After outlining the themes, as mentioned, Martin Heidegger's concepts served as the guideline to interpret the teachers' statements. To present the data and analysis, excerpts from the nursing teachers' reports were used.

\section{Results}

The nursing teacher is a being-there that goes through the experience as a being in the world, and relates with students, nurses and the health team in the context of a clinical service at a hospital, for a limited time period; different meanings are granted to this experience.

The first theme that emerges from the study refers to the way of being a teacher acting at the hospital together with the students:

\section{Being a teacher at the hospital}

(...) As time goes by I realize that, when I manage to see a student doing something, no matter how basic, I don't know, administering a drug, I find severe errors and that makes me question my way of distributing the students' work, but I also think that, if I don't, if we don't take all activities that come out, they lose enriching opportunities (I3).

(...) Because, in fact, there are factors that are producing tension. You are exposing yourself to criticism, to non acceptance in the patient who, if you repeat the technique and if the family finds out that this patient was attended by a student and was punctured multiple times, then your colleague can deny you the right to see to that patient again (I2).

(...) Teaching is also complex because, well, lately you have had to share eh (...) clinical areas with other universities (I3).

(...) Moreover, we sometimes share spaces with other units, unavoidably comparisons are made, and if these comparisons impair us at any time, that will also be a factor that will remain an opportunity not for one, but for all students (I5).

(...) One has the responsibility to take care to leave the areas open, to keep the theme inside positive, so that students learn (I5).

The teachers' contact with the nurse practitioners appears through this theme:

\section{Having contact with the nurse practitioners}

(...) I normally establish contact and try to maintain communication (...) with the nurse, (...) I believe that we are passing by, (...) and that she has to see clearly what happens or not at her service. If one does not respect that, the nurse (...) will start feeling that we are hindering her work and with good reason (I1).

(...) I depart from the base, although they are sometimes my former students or younger nurses, or with less experience, (...) one person is in charge, who is a colleague and I can't make her face up to what is decided about nursing, therefore, I believe that communication and respect for the colleague who is there is fundamental (I1). 
(...) My relation in general with the nurses at the service is quite good in (...) none of them was a nurse when I worked at that service, well, there is one who was but she's intermediary so I don't have a lot of contact with her, they are all younger or have worked less time at the hospital and (...) the relation is good (I3).

(...) For a good relation, first they need to validate you and, particularly to me, it's a plus (...) to try and visit the services where $I^{\prime} l l$ be in advance, and be there and participate in the work, get involved and get to know the standards, protocols, functioning, the daily routine at the unit, because that grants them the tranquility that you will be another team member and (...) they acknowledge you and make things easier for you (I5).

(...) They know that I've worked there, they are aware that the relation I have with the staff, at bottom they still call me the head, so, (...) to a certain extent that grants you some credibility among them (...) yes, I feel that some people (...) due to the fact of being at the university (...) they discredit you because they think that clinical practice is more important than what you do here at the university (I3).

(...) When we have been there sometimes, to (...) a same service, the road already lies open, then perceptions change, but the first is like this feeling of rejection, there is no academic awareness, no teaching awareness in hospitals (I4).

(...) Because the colleague is thinking that the house is being messed up, she thinks that you change the routine, although it's a contribution you are also proceeding with prudence in her work territory (I2).

(...) But it is also a process as a teacher because, when you leave, you have not only the salary, but also the clinical experience, the knowledge. (...) It is a work of professional maturity, personal maturity, knowledge reinforcement, and also in your equipment, as well as interaction with the student, also seeing how you are playing this tutor role, how to actually be a tutor (...). Being this tutor, I feel that (...) personally I learn by doing it (I5).

It has been (...) fundamental, to be able to put myself on an equal footing with them and to allow them to feel that I am another team member, and that has opened doors for me to be able to make it easier for students to get the opportunities because, otherwise, there's insecurity, because of the responsibility they feel for their work, their patients, they close your doors, deny you possibilities and, moreover, we sometimes share spaces with other units, unavoidably comparisons are made, and if these comparisons impair us at any time, that will also be a factor that will remain an opportunity not for one, but for all students (I5).

Teachers' experience with nursing students in clinical areas is verified in the following theme:

\section{Being a teacher in care education}

(...) The teaching one gives in hospital is student to student, (...) personalized, (...) it allows us (...) to capture better how students are, (...) it is very important (...) to work with small groups, to be able to deliver what one wants to deliver and observe whether students capture the idea of what nursing is or not (I1).

(...) To see how they have progressed, how they have gained confidence, how they are developing and gaining some degree of autonomy to be able to make decisions and be responsible for what they are (I5).

(..) I feel that I run a lot and that there is great pressure to perform a lot of techniques or many demands regarding quality for patients (I2).

(...) When I get to the hospital in the morning, what I commonly do is to distribute the students per room, I get two per room and if I have more students (...) leave someone in between. (...) I start to insist for them to finish dressings rapidly so that they aren't (...) when they bring in lunch (I2).

(...) One has to prepare the students for the frustration and not let them be used and get down thinking about the situation (I4).

(...) They perform a task, they provide support, they truly become substitutive elements, to be able to solve the patients' problems and attend to their needs (I3).

\section{Discussion}

Being a faculty at the hospital includes care delivery, task distribution, student supervision and support.

One way of being in the world is to be aware of its existence( ${ }^{(8)}$. When nursing teachers accompany students to the hospital, they enter a life-world different from their own, where the duration of their presence is limited, and where not they, but other health team members and patients are masters of the situation ${ }^{(10)}$.

Faculty members demonstrate insecurity when acting in this world of teaching. This step into the clinical world provokes anguish in teachers, pure anguish, without something specific that makes subject question their existence, which is rare. In general, it emerges from fear. Fear and anguish are very close feelings and, in most cases, they are inseparable, to the extent that subjects do not know whether they are afraid of what distresses them or whether they feel anguished by what they fear ${ }^{(8)}$.

In case of fear, what they are afraid of is always an entity in the world or coexistence with other subjects ${ }^{(8)}$. In nurses at the clinic and who coexist with teachers, anguish emerges in teachers when they feel insecure about fully and spontaneously sharing their I. 
Another very important aspect that provokes conflicts in teachers is the obligation to share the clinical area with other students from private colleges in the region, an aspect that causes bother because they face the unknown, comparisons among students. They feel responsible for making sure clinical areas remain open for their students.

Achieving cognitive, technical and affective skills demands much more of the so-called teaching subjects, given that content transmission requires a whole set of actions and procedures from mutually articulated educative agents, teachers and health professionals. In this sense, the need can be reaffirmed for everyone, teachers and health professionals, to commit to the formulation of the educative proposal(5).

In contact with nurse practitioners, the integration between these and nursing teachers presupposes opening to dialogue and acceptance of disagreements, so that the subjects in this relation can construct a highquality experience.

Being-with is one way of relating, feeling, thinking, acting, living with one's peers in the world, sharing with other people. This co-existence, being-with the other permits conditions to understand the other person's experience and see what he sees through his gestures, way of being, language( ${ }^{(8)}$.

The different modes the human being uses to relate include being-with, in the sense of the world, always being in the world shared with others. The world of the pre-sence is a shared world; therefore, being-in means being-with the others, and being-in-itself, within the material world of these others, is co-pre-sence ${ }^{(8)}$. According to Heidegger, this relation with the other is essential, as we are relational beings.

Nurses recognize themselves in the world as beings who share experiences. The relation with nurse practitioners is in line with respect for colleagues and their workspace, keeping up contact and communication, independently of their age or experience. Based on common agreement, the clinical burden and patients are distributed among the students.

In a research accomplished at a Brazilian institution, the authors observed and reported on the thin line that exists in the relation between nurse practitioners and nursing teachers, which provokes feelings of power, suffering and resistance ${ }^{(11)}$. The teachers' statements demonstrate their feelings in sharing their work with the nurse practitioners. Likewise, through their presence, the nurse practitioners, with their experiences and knowledge, share their work with the teachers.
Dasein means being-in-the-world, a being that is not alone, it is being-with (Dasein-con) and, thus, being-in-relation. Thus, pre-sence is not only being-inthe-world, but also relating with the world, according to a predominant way of being. In the world, Dasein is inserted in a context of fact( ${ }^{(8)}$.

Everything is always beings, being-with oneself in solitude or isolation, the world is always shared, living is always an experience ${ }^{(8)}$. Even when the teacher's being-there is isolated from others, or manages a way of living without them, this is still a way of being-with, in a deficient relation of being-with.

In their professional work, nurses involve their history, their way of being, their living, their experience, expressed in their discourse, in which the teachers report how they have professionally developed over time and the experience they have gained.

A study of nurse practitioners who are in contact with nursing students found that they also feel the pressure to be up-to-date in terms of theory ${ }^{(12)}$. Teachers should keep their practical knowledge updated and be skilled in care delivery so as to be-with the nurse practitioners, in the sense of always being.

Being set implies that a person has a past, a present and a future and that all aspects influence the current situation. People get into a situation with their own set of meanings, customs and perspectives. Present care is fed by meanings from the past, and enriched by the anticipation of the future. The future is the present that is about to come, and what is of interest in care is the present. It is the growth during action ${ }^{(13)}$.

It is considered that sensitivity, intuition and empathy constitute forms of access to the other, and therefore permit a revealing description that gives meanings to the other person's being with regard to what is shown through the experience lived. It is not a behavior that can be freely adopted, but is determined by convictions, values and needs rooted in the personal. It has to do with what we think, feel and do; it has to do with what we are. Subjects' co-participation in shared experiences allows them to understand and interpret them.

Besides contributing with the concept of beingin-the-world, Heidegger develops the care concept: of being with the others in the world, concern with the others. According to Heidegger, "care" has a double meaning, and these two meanings present two conflicting and fundamental possibilities ${ }^{(8)}$. According to this phenomenologist, we are beings-of-care.

Care also entails the meaning of interest in or care for, seeing to, being concerned with our peers, as a 
meaning opposed to mere care for them. Thus, being a care teacher, from an education perspective, is what determines a proper or authentic relation with the others.

The care teachers provide is expressed as letting the student subjects show their true being, as letting them be, as making sure all students show themselves in their being, end up being what they are. This can take the form of nursing teachers helping students to develop their full potential and possibilities of being(14). Thus, teachers who get involved in care know that they will be capable to help the other grow at their own rhythm, and will be responsible for their students' growth and development(13). Thus, the nursing teachers' relation with their students will not be marked by domination, but by coexistence; not only by intervention, but by interaction, so as to be able to assume their own existence and transcend their being.

Teaching activities still reflect a highly technical practice. Several times, teachers get an activity overload in the attempt to please their students, the nurse practitioners and the patient. When care is not authentic, nursing teachers take care of the students' needs in a functional way. This type of care requires few qualities, mainly restriction, so as to perform the service well. It makes them consider the students as "things" to take care of, ignoring that they are individuals and oriented towards others. In this care, students are not objects of service, but of interest ${ }^{(15)}$.

A study on nurse practitioners' experience with nursing students demonstrated that the care relation nursing teachers describe is the same observed in this study. The care relation observed in teachers is equally present in nurse practitioners, when they allow the students or not to develop their full potential or not ${ }^{(12)}$.

Student training requires not only technical, but also affective skills. Achieving these aspects demands more; transmitting the contents of course subjects alone implies incorporating a broad care act, in the framework of the personal relation. In other words, adding nursing care actions to attention for the other, commitment to the other, respect and empathy.

Being with students in their education process entails responsibility, commitment, which the three actors share: teacher, nurse practitioner and student. In this sense, all health professionals and academic professionals need understanding in the formulation of educative proposals.

\section{Final considerations}

Unveiling the phenomenon of the experience of being a nursing teacher, who works with undergraduate students in clinical training areas, allowed us to understand the relevance of the educative process considering ways of being, communication, affect, language, time and space, among others.

As being-there, nursing teachers can transcend being-with-the-other in the world, understanding other people in their existence and in their world and, at the same time, having the possibility to transform this world, because it is permanently being.

Preparing new nursing professionals is a complex task that demands competences from teachers, not only related to their knowledge, but also to the skills gained in their own experience as beings. These skills will be applied in real time, in a complex environment like the clinical area, an environment that necessarily involves the relation with patients, students, nurse practitioners and health teams.

As nursing teachers, the researchers consider that knowledge production results from education. In this educative process, the creative gesture that result from man's being in the world and relating with it needs to be taken into account, which enables him to transform this world and, in this process, get transformed. On the other hand, knowledge dissemination enhances the teaching team and the nurses' reflection on the educative meaning of their function, identifying teams for improvement in the care process for students and patients.

Research on this theme needs to be broadened, considering that, as observed, this is an important part of future nursing professionals' learning process. Moreover, a review of available production on the theme at the South American level reveals difficulties to find similar studies in order to enrich the discussion presented.

Likewise, colleges should constantly aim to approach teaching with clinical care, as a constructive and facilitating element of the teaching process, with a view to preparing new nursing professionals who entail the bases of authentic care in their actions and involve teachers, nursing students and patients in this care, as active participants in their important function.

\section{References}

1. Ito EE, Takahashi RT. Publicações sobre ensino em enfermagem na revista da escola de enfermagem da USP. 
Rev Esc Enferm USP. [internet]. dez 2005. [acesso 15 mar 2010]; 39(4):409-16. Dispon'vel em: http://www. scielo.br/scielo.php?script $=$ sci_arttext\&pid $=$ S0080$62342005000400006 \&$ Ing $=$ en. doi: 10.1590/S008062342005000400006

2. Scherer ZAP, Scherer EA. Reflexiones sobre la enseñanza de enfermería en la postmodernidad y la metáfora de una laguna teórico-práctica. Rev. Latino-Am. Enfermagem. [internet]. maio-junho 2007. [acesso 15 mar 2010], 15(3):498-501. Disponível em: http://www. scielo.br/scielo.php?script=sci_arttext\&pid=S008062342005000400006\&lng=en. doi: 10.1590/S008062342005000400006 .

3. Guedes GF, Ohara CVS, Silva GTR, Franco GRRM. Ensino clínico na enfermagem: a trajetória da produção científica. Rev Bras Enferm [internet]. abril 2009; [acesso 15 mar 2010], 62(2):283-6. Disponível em: http://www. scielo.br/scielo.php?script =sci_arttext\&pid=S003471672009000200018\&lng=en. doi: 10.1590/S003471672009000200018.

4. Moya JLM, Parra SC. La enseñanza de la enfermería como práctica reflexiva. Texto Contexto Enferm. [internet]. Junho 2006; [acesso 16 mar 2010]; 15(2):303-11. Disponível em: http://www.scielo. br/scielo.php?script =sci_arttext\&pid=S010407072006000200015\&lng=en. doi: 10.1590/S010407072006000200015

5. Caetano JA, Diniz RCM, Soares E. Integração docente-assistencial sob a ótica dos profissionais de saúde. Cogitare Enferm. [Internet]. out-dez 2009; [acesso 12 jun 2010]; 14(4):638-44. Disponível em: http://ojs.c3sl.ufpr.br/ojs2/index.php/cogitare/article/ view/16376/10857

6. Valsecchi EASS, Nogueira MS. Comunicação professor-aluno: aspectos relacionados ao estágio supervisionado. Ciênc Cuidado Saúde [internet]. 2002 primeiro semestre [acesso 12 jun 2010]; 1(1):137-43. Disponível em: http://periodicos.uem.br/ojs/index.php/ CiencCuidSaude/article/viewFile/5684/3608

7. Gonzales Rey F. Pesquisa cualitativa e subjetividade: os processos de contrução de informação. São Paulo: Thompson; 2005.

8. Heidegger M. El ser y el tiempo. Tercera reimpresión de la segunda edición. Colombia: Ed. Fondo de Cultura Económica; 1998.

9. Martins J, Bicudo MA. A pesquisa cualitativa en psicología: Fundamentos y recursos básicos. $2^{\mathrm{a}}$ ed. Blumenau: Editora Moraes; 1994.

10. Pereira WR. As relações de poder no universo de enfermeras-docentes. Rev Gaúcha Enferm. [internet]. jan 1999 [acesso 20 jun 2010]; 20(1):41-56. Disponível em: http://seer.ufrgs.br/ index.php/RevistaGauchadeEnfermagem/article/ viewFile/4220/2230

11. Ferreira EM, Fernandes MFP, Prado C, Baptista PCP, Freitas GF, Bonini BB. Prazer e sofrimento no processo de trabalho do enfermeiro docente. Rev Esc Enferm USP [internet]. dez 2009 [acesso 9 ago 2010]; 43(spe2):1292-6. Disponível em: http://www.scielo.br/ pdf/reeusp/v43nspe2/a25v43s2.pdf

12. Santos MF, Merighi MA, Muñoz LA. Las enfermeras clínicas y las relaciones con los estudiantes de enfermería: un estudio fenomenológico. Texto Contexto Enferm. [internet]. 2010 janeiro [acesso 16 ago 2010]; 19(1):112-9. Disponível em: http://www.scielo.br/pdf/ tce/v19n1/v19n1a13.pdf

13. Waldow VR. Enseñanza de enfermería centrada en el cuidado. Aquichan. [internet] dez 2009. [acesso 16 ago 2010]; 9(3):246-56. Disponível em: http://redalyc. uaemex.mx/pdf/741/74112147005.pdf

14. Terra MG, De Mello PSM, Goncalez LHT, Santos EKA, Erdmann AL. O dito e o não dito do ser - docente - enfermeiro/a na compreensão da sensibilidade. Rev Bras Enferm. [internet] out 2008. [aceso 20 jun 2010]; 61(5):558-64. Disponível em: http://www. scielo.br/scielo.php?script $=$ sci_arttext\&pid $=$ S003471672008000500005\&lng=en. doi: 10.1590/S003471672008000500005

15. Martini JG. O currículo e a formacao do enfermeiro. Rev Bras Enferm. [internet]. ago 2008. [acesso 17 2010 ago]; 61(4):407. Disponível em: http://www. scielo.br/scielo.php?script $=$ sci_arttext\&pid $=$ S003471672008000400001\&lng=en. doi: 10.1590/S003471672008000400001
Received: Sep. $15^{\text {th }} 2010$ Accepted: Feb. $9^{\text {th }} 2011$ 